\title{
Effect of Aqueous Extract Cyperus rotundus Tubers as Antioxidant on Liver and Kidney Functions in Albino Males Rats Exposed to Cadmium Chloride Toxic
}

\author{
Adnan Mohammed Ahmeed Aldulaimi ${ }^{1^{*}}$ \\ Feryal Farooq Husain ${ }^{2}$
}

\author{
Received 1/10/2018, Accepted 22/1/2019, Published 2/6/2019
}

This work is licensed under a Creative Commons Attribution 4.0 International License.

\begin{abstract}
:
The experiment was conducted in two stages: first stage: determination of the most effective dose of Cyperus rotundus tubers aquatic extract in male rats for 5 days, which was concentrated as $(200 \mathrm{mg} / \mathrm{kg}$ body weight). The second stage was designed to observe and test the protective effects of $C$. rotundus tubers aquatic extract in the liver and kidney functions of male rats exposed to cadmium chloride poisoning (5 $\mathrm{mg} / \mathrm{kg} \mathrm{bw}$ ) for 30 days. The animals were divided into (4) groups within each group (5) animals weighted $(200-220 \mathrm{~g})$. The results of oral dose of cadmium chloride showed a significant increase of $(\mathrm{P}<0.05)$ in the activity of both enzymes Alanine aminotransferase (ALT), Aspartate aminotransferase (AST), Alkaline phosphatase (ALP), glucose, urea, uric acid, creatinine, malondialdehyde (MDA) and peroxynitrite (ONOO ). And a significant decrease $(\mathrm{P}<0.05)$ in the values of total protein, albumin, globulin and glutathione $(\mathrm{GSH})$ compared with the control group. The oral dosage of the $C$. rotundus tubers aquatic extract resulted in a significant increase in GSH. The values of each were not significantly different ALT, AST, ALP, Glucose, urea, uric acid, creatinine, total protein, albumin, globulin, MDA and peroxy nitrite Compare with control group. The results of the oral dosage with (C. rotundus tubers aquatic extract + cadmium chloride) showed a positive effect on these values compared with the control group and cadmium chloride. It is concluded that the $C$. rotundus tubers aquatic extract has protective effects and reduces the effects that cadmium chloride can cause in rats liver and kidney functions through its antioxidant activity and removal of free radicals.
\end{abstract}

Key words: Cadmium chloride, C. rotundus, Liver and kidney functions.

\section{Introduction:}

Cumulative effect of urbanization, industrialization and population growth increases pressure on the limited natural resources. The change in living style has aggravated the problems. Among the diverse environmental problems and increasingly serious, the discharge of heavy metals in environment through industrial, agricultural and domestic activities is of great concern (1). Cadmium (Cd) a heavy metal of considerable toxicity, is one of the most widely existed toxic environmental pollutants. Industrial production such as batteries manufacture, pigments generation and metal plating obviously enhances the risk for the contamination of $\mathrm{Cd}$ in the atmosphere, chemical fertilizers, water and soil (2). As a result, people are exposed to $\mathrm{Cd}$ from air, drinking water and so on. Especially, tobacco smoking is another important way for people exposed to $\mathrm{Cd}(3,4)$. welding, and contaminated food and beverages(5).

\footnotetext{
1 Education Directorate Salah Al-Deen, Ministry of Education, Salah Al-Ddeen, Iraq.

2 Food Science Department, College of Agriculture, University of Tikrit, Tikrit, Iraq.

*Corresponding author: Adnanmoh77@gmail.com
}

(Cd) This metal presents the serious threat for both, humans and animals health, The environmental risk can lead to the absorption of large quantities of $\mathrm{Cd}$ and its toxic action on organisms, It adversely affects some organs in humans and animals, including the liver, kidneys, lungs, pancreas, and testis (6). (Cd) is one of the most common and harmful transition metals present in our environment. Unfortunately, this nonessential element is toxic at very low doses and non-biodegradable by a very long biological halflife (7).

Increasing attention is given to the study of natural products, which may counteract the detrimental effects of environmental toxic compounds and prevent multiple human diseases such as neurodegenerative diseases, ageing, rheumatoid arthritis, metabolic diseases such as atherosclerosis, diabetes, hypertension, cancer, etc.. In this line, different medicinal plants have been reevaluated and recognized as valuable sources of nutraceuticals(8). Recently, several dietary supplements containing vitamins, polyphenols, or flavones also play a significant role in this matter. 
Phenolic compounds are very important plant constituents because they exhibit an antioxidant activity by inactivating lipid free radicals or preventing decomposition. C. rotundus belonging to family-Cyperaceae is widely used in traditional medicine around the world for the treatment of various diseases and used in antiinflammatory, antidiabetic, antidiarrhoeal and antipyretic (9). hypolipidemic, hepatoprotective and antimicrobial properties (10). Anti-oxidant activity (11). C. rotundus contains some effective compounds that include flavonoids, tannins, glycosides, monoterpenes, sesquiterpenes, sitosterol, alkaloids saponins, terpenoids, essential oils, starch, carbohydrates, protein and amino acids (10). The study aims to know the protective of $C$. rotundus tubers aquatic extract antioxidant in liver and kidney functions in males albino rats exposed to cadmium chloride.

\section{Materials and Methods: \\ Collection and preparation of samples:}

C. rotundus was obtained from local markets and was diagnosed by specialists in University of Tikrit - College of Agriculture Department of Horticulture and was fresh and dry. It was cleaned from foreign materials and then grinded with a national electric blender (Japan) for a fine powder.

\section{Extract preparation:}

The aqueous extract was obtained using method (12), $100 \mathrm{~g}$ of $C$. rotundus powder was weighed in an analytical balance. In a flask add 200 $\mathrm{ml}$ of distilled water and leave for 24 hours in the refrigerator after stirring, The treatment was then mediated by the medical gauze. The washing process was then using $100 \mathrm{~mL}$ of distilled water and the filtration was repeated. The washing and refiltration process was then repeated, using $50 \mathrm{~mL}$ distilled water. Vaporizer display for evaporation using rotary vapor evaporator At $70 \mathrm{C}^{\circ}$ until a concentrated liquid is obtained. Finally, the extract is placed in plastic containers that are known as freezing at $-20 \mathrm{C}^{\circ}$ until use.

\section{Detection of active compounds in $C$. rotundus extract:}

Each of the following active compounds was detected using their respective method, Resins (12). Flavones (13). Phenoles, Saponines (14). tannins (15). Alkaloids (16, 13). Coumarins (17).

\section{Animals used in the study:}

Rattus norvegicus of the (Sprague dawely) (200-220 g), obtained from the National Center for Control and Drug Research in Baghdad. It was placed in metal cages with metal covers and

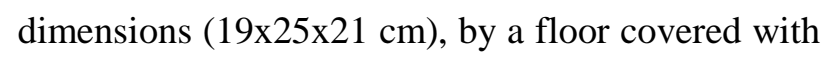
sawdust. The cages cleaning and sterilization were taken care of with crosswise switch every two days. The animals were subjected to laboratory conditions from a light cycle divided into 12 light hours and 12 hours of darkness. The temperature was set at $22 \pm 2$ $\mathrm{C}^{\circ}$. The animals were left for two weeks for adaptation. The animals were fed with fodder consisting of $35 \%$ wheat, $34 \%$ yellow corn, $20 \%$ soybean, $10 \%$ animal protein, $1 \%$ powdered milk, $50 \mathrm{~g}$ preservatives and antifungal substances (18). They were standard food, water ad libitum in adequate amounts all through for the experimental period. The experiment was conducted in two stages.

\section{The first stage: Determination of the effective dose.}

This is a pilot study to determine the most effective and optimal dose of $C$. rotundus aqueous tubers extract reduced for glucose and cholesterol in the blood. Healthy animals were randomly divided into (5) groups containing each group (3) animals, distributed as follows:

Group (1): (Group control): it was given distilled water.

Group (2): (100 mg/kg body weight) was from the C. rotundus extract.

Group (3): (200 mg/kg body weight) was of $C$. rotundus extract.

Group (4): (400 mg/kg body weight) was of $C$. rotundus extract.

Group (5): (800 mg/kg body weight) was of $C$. rotundus extract.

They were administered daily and over five days, after which blood samples were withdrawn by the venous vein which may blood collection (19). And the measurement of concentrations of glucose and cholesterol in them and was selected the most effective dose of the extract was $(200 \mathrm{mg} / \mathrm{kg}$ body weight).

\section{The second stage:}

The animals were divided into (4) groups that included five (5) animals and close weights as follows:

Group 1: Control group.

Group 2: administered orally cadmium chloride (5 $\mathrm{mg} / \mathrm{kg}$ of b.wt) by gavage daily for period (30) days (20).

Group 3: administered orally $C$. rotundus extract ( $200 \mathrm{mg} / \mathrm{kg}$ of b.wt) by gavage daily for period 30 days.

Group 4: This was given (C. rotundus extract 200 $\mathrm{mg} / \mathrm{kg}+$ cadmium chloride $5 \mathrm{mg} / \mathrm{kg}$ ) daily for 30 days. 


\section{Blood samples:}

After 30 days, animals were starved for 10 hours, They were then weighted and numbed with chloroform. The blood samples were then removed by cutting were jugular vein in the neck, collecting about $6-8 \mathrm{ml}$ of blood. Test tubes free of anticoagulant left for about a quarter of an hour in a water bath at $37 \mathrm{C}^{\circ}$ until coagulation and then placed in the centrifuge for 15 minutes at 3000 cycles / minute, and the serum was withdrawn by micro-pipette and placed in new plastic tubes and cleaned (Plane tubes) and kept at $-20 \mathrm{C}^{\circ}$ until the conduct of special biochemical tests, which include both glucose, urea, uric acid, creatinine, total protein Albumin, ALT, ALP, AST and using several standard solutions (Kits) manufactured by BIOLABO SA, France (12).

The concentration of malondialdehyde (MDA) in the serum was estimated using method (21).

glutathione (GSH) was estimated in the serum using the method used by $(22,23)$.

The concentration of the Peroxynitrite radical was estimated using the method (24).

The Determination globulin in blood serum according to the following equation (25).

Concentration of globulin $(\mathrm{g} / \mathrm{dl})=$ Total protein Conc. - Albumin Conc.

\section{Statistical analysis:}

The results were analyzed statistically and using SAS, 2001, according to one-way analysis of variance. The mean of the coefficients was tested using the Duncun multiple rang test at a significant level $(0.05)$ to determine the significant differences between the aggregates (23).

\section{Results:}

\section{Detection of active compounds in the extract:}

Table (1) indicates that the $C$. rotundus aqueous extract contains active substances that include Resins, Saponins, Tannins, Alkaloids, Coumarin, Flavonoids and Phenols. volatile oils, terpenes, steroids. These results agreed with those of (26) C. rotundus contained flavonoids, tannins, glycosides, monoterpenes, sitosterol, alkaloids, saponins, terpenoids, essential oils, starch, carbohydrates and proteins.
Table 1. Type of active compounds found in the C. rotundus aqueous extract.

\begin{tabular}{|c|c|c|c|c|c|c|c|}
\hline 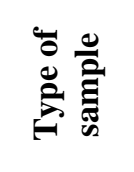 & $\stackrel{\mathscr{0}}{\mathscr{E}}$ & 告 & • & 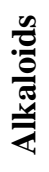 & 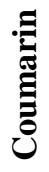 & 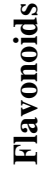 & $\frac{n}{0}$ \\
\hline $\begin{array}{c}C . \\
\text { rotundus } \\
\text { extract }\end{array}$ & + & + & + & + & + & + & + \\
\hline
\end{tabular}

\section{Effective dose determination:}

Table (2) shows the effect of $C$. rotundus aqueous extract on reducing the concentration of glucose and cholesterol in healthy male white rats in order to determine the most effective dose. This dose was found to be $200 \mathrm{mg} / \mathrm{kg}$ bw, it was adopted as a used dose for the substances under study.

Table 2. Determination of effective dose of $C$. rotundus aqueous extract in glucose and cholesterol parameters in male white rats.

\begin{tabular}{lccc}
\hline group & $\begin{array}{c}\text { Concentration } \\
\text { ( mg/kg body } \\
\text { weight) }\end{array}$ & $\begin{array}{c}\text { Glucose } \\
(\mathbf{m g} / \mathbf{d l})\end{array}$ & $\begin{array}{c}\text { Cholesterol } \\
(\mathbf{m g} / \mathbf{d l})\end{array}$ \\
\hline control & 0.0 & $110 \mathrm{AB}$ & $95.33 \mathrm{AB}$ \\
& & \pm 2.30 & \pm 1.45 \\
& 100 & $109 \mathrm{AB}$ & $93.66 \mathrm{BC}$ \\
& & \pm 2.30 & \pm 2.40 \\
C. & 200 & $106 \mathrm{~B}$ & $88.00 \mathrm{C}$ \\
rotundus & & \pm 1.73 & \pm 2.30 \\
extract & 400 & $113 \mathrm{AB}$ & $90.00 \mathrm{BC}$ \\
& & \pm 2.30 & \pm 1.73 \\
& \multirow{2}{*}{00} & $114 \mathrm{~A}$ & $97.33 \mathrm{~A}$ \\
& & \pm 1.73 & \pm 0.88 \\
\hline
\end{tabular}

The figures followed by vertically different letters mean that there are significant differences at the probability level $(\mathrm{P} \leq 0.05)$.

Table (3) effect orally feeding of $C$. rotundus aqueous extract in the activity of blood serum enzymes of male rats exposed to cadmium chloride poisoning. The oral dose of cadmium chloride at a concentration of $5 \mathrm{mg} / \mathrm{kg}$ body weight for 30 days significantly increased $(\mathrm{P}<0.05)$ in the efficacy values of ALP, AST and ALT. The oral dosage of C. rotundus aqueous extract at $200 \mathrm{mg} / \mathrm{kg}$ body weight for 30 days in male rats resulted in no significant difference in the efficacy of ALP, AST and ALT compared with control group. Treatment with (C. rotundus + cadmium chloride) significantly reduced $(\mathrm{P}<0.05)$ in enzyme activity compared to control with cadmium chloride. 
Table 3. Effect of orally administration of $C$. rotundus aqueous extract in the activity of blood enzymes in male rats exposed to cadmium chloride poisoning.

\begin{tabular}{cccc}
\hline \multirow{2}{*}{$\begin{array}{c}\text { Type of } \\
\text { transaction }\end{array}$} & \multicolumn{3}{c}{ Measured Standards (IU/L) } \\
\cline { 2 - 4 } & ALP & AST & ALT \\
\hline control & $211.0 \mathrm{C}$ & $43.52 \mathrm{C}$ & $29.62 \mathrm{~B}$ \\
& \pm 0.70 & \pm 0.30 & \pm 0.33 \\
& $295.0 \mathrm{~A}$ & $69.00 \mathrm{~A}$ & $40.00 \mathrm{~A}$ \\
Cadmium chloride & \pm 1.84 & \pm 1.16 & \pm 1.53 \\
& $209.0 \mathrm{C}$ & $43.00 \mathrm{C}$ & $28.90 \mathrm{~B}$ \\
C. rotundus & \pm 0.74 & \pm 0.35 & \pm 0.32 \\
extract & $263.0 \mathrm{~B}$ & $60.20 \mathrm{~B}$ & $36.40 \mathrm{~A}$ \\
C. rotundus+ & \pm 1.39 & \pm 1.01 & \pm 1.14 \\
cadmium chloride & & & \\
\hline
\end{tabular}

The figures followed by vertically different letters mean that there are significant differences at the probability level $(\mathrm{P} \leq 0.05)$.

Tables (4 and 5) indicate the effect of the oral dosage of the $C$. rotundus aqueous extract in some physiological and biochemical parameters in the serum of male white rats exposed to cadmium chloride. The oral dose cadmium chloride at a concentration of $5 \mathrm{mg} / \mathrm{kg}$ body weight for 30 days resulted in a significant decrease $(\mathrm{P}<0.05)$ in total protein, albumin, and globulin, and significant increase in glucose, uricacid, urea and creatinine compared with the control group.The oral dosage of the C. rotundus aqueous extract of $200 \mathrm{mg} / \mathrm{kg}$ body weight for 30 days in male rats resulted in significant differences in total protein values, albumin, globulin, glucose, uric acid, urea and creatinine compared with control group.Treatment with $(C$. rotundus + cadmium chloride) resulted in an improvement in these values compared to control with cadmium chloride.

Table 4. Effect of orally feeding of $C$. rotundus aqueous extract in protein concentrations in blood serum male rats exposed to cadmium chloride poisoning.

\begin{tabular}{cccc}
\hline \multirow{2}{*}{$\begin{array}{c}\text { Type of } \\
\text { transaction }\end{array}$} & \multicolumn{2}{c}{ Measured Standards (g/dl) } \\
\cline { 2 - 4 } & $\begin{array}{c}\text { Total } \\
\text { protein }\end{array}$ & Albumin & Globulin \\
\hline control & $6.90 \mathrm{~A}$ & $3.90 \mathrm{~A}$ & $3.00 \mathrm{~A}$ \\
& \pm 0.33 & \pm 0.34 & \pm 0.42 \\
Cadmium & $4.50 \mathrm{~B}$ & $2.84 \mathrm{~B}$ & $1.46 \mathrm{~B}$ \\
chloride & \pm 0.14 & \pm 0.17 & \pm 0.12 \\
C. rotundus & $7.60 \mathrm{~A}$ & $4.30 \mathrm{~A}$ & $3.30 \mathrm{~A}$ \\
$\quad$ extract & \pm 0.33 & \pm 0.33 & \pm 0.66 \\
C. rotundus + & $5.12 \mathrm{~B}$ & $2.60 \mathrm{~B}$ & $2.52 \mathrm{AB}$ \\
$\quad$ cadmium & \pm 0.15 & \pm 0.40 & \pm 0.42 \\
\hline chloride & & \\
\hline
\end{tabular}

The figures followed by vertically different letters mean that there are significant differences with the probability level $(\mathrm{P} \leq 0.05)$.

Table 5. Effect orally feeding of $C$. rotundus aqueous extract in the Urea, uric acid, creatinine, glucose of male rats exposed to cadmium chloride poisoning.

\begin{tabular}{ccccc}
\hline \multirow{2}{*}{ Type of transaction } & \multicolumn{4}{c}{ Measured Standards (mg/dl) } \\
\cline { 2 - 5 } control & Urea & uric acid & Creatinine & Glucose \\
& $45.40 \mathrm{~B}$ & $4.1 \mathrm{~B}$ & $0.81 \mathrm{~B}$ & $115.5 \mathrm{~B}$ \\
& \pm 0.34 & \pm 0.23 & \pm 0.07 & \pm 0.70 \\
Cadmium chloride & $53.00 \mathrm{~A}$ & $6.4 \mathrm{~A}$ & $1.90 \mathrm{~A}$ & $131.3 \mathrm{~A}$ \\
& \pm 2.22 & \pm 0.33 & \pm 0.32 & \pm 1.17 \\
C. rotundus extract & $45.00 \mathrm{~B}$ & $4.6 \mathrm{~B}$ & $0.87 \mathrm{~B}$ & $110.6 \mathrm{~B}$ \\
C. rotundus + cadmium & \pm 0.35 & \pm 0.43 & \pm 0.32 & \pm 1.84 \\
chloride & $49.90 \mathrm{~B}$ & $5.6 \mathrm{~A}$ & $1.00 \mathrm{~B}$ & $126.0 \mathrm{~A}$ \\
& \pm 0.33 & \pm 0.11 & \pm 0.11 & \pm 1.14 \\
\hline
\end{tabular}

The figures followed by vertically different letters mean that there are significant differences at the probability level $(\mathrm{P} \leq 0.05)$.

Table (6) shows the effect of $C$. rotundus aqueous extract in some antioxidants and parameters in the blood of male rats exposed to cadmium chloride.

As shown by the Table, the effect of cadmium chloride resulted in a significant decrease $(\mathrm{P}<0.05)$ in GSH and a significant increase $(\mathrm{P}<0.05)$ in MDA and peroxynitrite compared to control group.The oral dose of a $200 \mathrm{mg} / \mathrm{kg}$ body C. rotundus aqueous extract in male rats for 30 days resulted in a significant increase $(\mathrm{P}<0.05)$ in $\mathrm{GSH}$ and no significant difference in MDA and peroxynitrite compared to the control group. The treatment of $(C$. rotundus + cadmium chloride) improved the values of GSH, MDA and peroxynitrite compared to control with cadmium chloride. 
Table 6. Effect of orally feeding of $C$. rotundus aqueous extract in Glutathione of male rats exposed to cadmium chloride poisoning.

\begin{tabular}{cccc}
\hline \multirow{2}{*}{ Type of transaction } & \multicolumn{3}{c}{ Measured Standards (Mmol/L) } \\
\cline { 2 - 4 } & Glutathione & Malondialdehyde & Peroxynitrite \\
\hline the control & $460.1 \mathrm{~B}$ & $1.52 \mathrm{C}$ & $59.2 \mathrm{C}$ \\
& $3.53 \pm$ & $0.17 \pm$ & $1.00 \pm$ \\
Cadmium chloride & $303.0 \mathrm{D}$ & $3.90 \mathrm{~A}$ & $75.3 \mathrm{~A}$ \\
& $1.58 \pm$ & $0.07 \pm$ & $1.14 \pm$ \\
C. rotundus extract & $490.0 \mathrm{~A}$ & $1.61 \mathrm{C}$ & $60.2 \mathrm{C}$ \\
& $3.53 \pm$ & $0.17 \pm$ & $0.51 \pm$ \\
C. rotundus + cadmium & $399.0 \mathrm{C}$ & $3.00 \mathrm{~B}$ & $70.1 \mathrm{~B}$ \\
chloride & $4.25 \pm$ & $0.18 \pm$ & $0.66 \pm$ \\
\hline
\end{tabular}

The figures followed by vertically different letters mean that there are significant differences at the probability level $(\mathrm{P} \leq 0.05)$.

\section{Discussion:}

The reason for the rise in the level of these enzymes indicates liver damage from the effect of cadmium chloride (27). This can lead to the necrosis of the liver which causes increasing permeability of the cell membrane leading to secretion or transmission of transaminases enzymes in the bloodstream, and that increasing in alkaline phosphatase represents general hepatic toxicity (28). Alkaline phosphates are usually the response of the liver to any form of bile duct obstruction (29) The liver is one of the critical target members of cadmium toxicity that causes liver necrosis and can cause abnormal release of ALT and AST in the blood (30).

The reason for the increase in urea may be due to increased concentrations of free radicals in the body and the occurrence of oxidative stress and cause oxidation of proteins and amino acids and thus increase urea as a secondary product (31). The increase can be due to the increase of pyurines, which are the basic materials for the formation of uric acid, which may result from the destruction of nucleic acids, and that cadmium destroys DNA (32). The reason for the significant increase in serum creatinine concentration may be due to nonfiltration of creatinine from the blood through renal glomeruli due to damage and damage caused by glomeruli due to oxidative damage to cadmium chloride, allowing the release of creatinine in the blood (33). The decrease of proteins in the cadmium chloride group can cause effect-free radicals resulting from oxidative stress leading to diabetic nephropathy and increasing the amount of blood-tourine protein (albumin) through the glomerular glands $(34,35)$.

The damage of cadmium chloride in the liver and kidneys, induced the over-generated ROS and diminished antioxidant enzymes lead to uncontrolled oxidative stress. Oxidative stress stimulates the damages of DNA, lipids, proteins and other cellular biomolecules, as well as promoting the interruption of cellular redox homeostasis, the cellular apoptosis and the abnormal activation of signaling pathways $(36,37)$. The reason for the increase in the concentration of MDA in animals exposed to oxidtive stress is the result of treatment with cadmium chloride, which may result in the formation of free radicals that attack the fat and its compounds in the body, especially in the cellular membranes and work on oxidation and damage. This process is called lipid peroxdation, and the result of lipid peroxdation is MDA (Malondialdehyde) $(38,39)$ MDA is a lipid peroxidation product from polyunsaturated fatty acids and commonly used to be an indicator of oxidative damages in cellular and organic functions $(40,41)$. In addition, the concentration of peroxynitrite (ONOO-) in the serum, which may be attributed to increased production of freeradicals, especially the superoxide oxide $\left(\mathrm{O}_{2}^{-}\right)$, was observed directly, which in turn reacted with nitricoxide to produce ONOO-, which is more oxidized of both $(42,43)$. This is due to the increase in the formation of free radicals, especially ROS, and the occurrence of oxidative stress, which cause oxidation of glutathione as a result of its antioxidant effect. Thus converting it to the oxidative form Glutathione disulfide (GSSG), which is toxic and stimulates the production of new varieties of free radicals (44, 45).The reason for the decrease in the enzymes activity when treated with a $C$. rotundus extract may be due to the hepatoprotective effect of could be attributed to the improvement of antioxidant status of the animals of the presence of free radical scavenging substances such as flavonoid (46). May be due to the that flavonoids can repair damaged liver cells through removing free radicals, causing the decrease in the level of enzymes activity (47). Or possibly due to liver activation can be attributed to the ability of cell membrane stability to prevent the enzyme from leaking out (48). The significant increase in the total proteins of the blood serum treated with $C$. rotundus extract may be due to the effectiveness of the antioxidant components, which play an important role in reducing oxidative stress. 
This is reflected in the inhibition of cortisone secretion of the adrenal cortex, which plays role in the formation of glucose from non-carbohydrate sources, thus preserving the amino acids Gluconeogenesis also maintains or elevates the level of plasma proteins (49). This may be due to the role of the antioxidants in this extract in the induction of the process of making proteins in different locations in the body of the organism where the presence of flavonoids in the $C$. rotundus tubers used in the study anti-oxidation effectively plays an important role in reducing peroxide and increase catalysts Catalase and prevent oxidation in animals (50). The reason for the low blood glucose level is that the $C$. rotundus aqueous extract contains active substances with insulin-like effects (51). Previous studies have showed that $C$. rotundus compounds inhibit the free radical generation, act as antioxidant, free radical scavengers and it has also been demonstrated that treatment with $C$. rotundus inhibits the generation of superoxide radicals (52, $53,54)$. The reason for the increase in glutathione may be due to the content of $C$. rotundus on antioxidants, including multiple phenolic compounds and flavonoids, which may inhibit the reactions of the formation of free radicals and remove the radicals resulting from the impact of cadmium chloride, and activates the liver and stimulate the enzymes of liver antioxidants such as glutathione Peroxidase (Gpx) Catalase and superoxide dismutase (SOD) superoxide dismutase, all of which inhibit oxidation and lipid peroxidation and inhibit the production of melonadealdehyde $(55,56)$. The overall antioxidant activity of $C$. rotundus extract might be attributed to its polyphenolic content and other phytochemicals constituents which exhibit and reduce free radical scavenging (56). In conclusion our study indicates that $C$. rotundus aqueous extract have Liver and kidney protection effect against cadmium chloride induced oxidative stress in rats which may be related to its antioxidant effect.

\section{Conflicts of Interest: None.}

\section{References:}

1. Sharma A, Sachdeva S. Cadmium Toxicity and Its Phytoremediation A review. Int. J. Sci.Eng. Res. 2015; 6(9): 395-405.

2. Adaramoye OA, Akanni OO. Modulatory effects of methanol extract of artocarpus altilis (Moraceae) on cadmium-induced hepatic and renal toxicity in male Wistar rats. Patho- physiology. 2016; (23): 1-9.

3. Jianwu HU, Zhang BO, Lifen DU, Chen J, Qiaofa LU. Resveratrol ameliorates cadmium induced renal oxidative damage and inflammation. Int $\mathbf{J}$ Clin Exp Med 2017;10(5):7563-7572.
4. Adefegha SA, Omojokun OS, Oboh G. Mo- dulatory effect of protocatechuic acid on cadmium induced nephrotoxicity and hepatoxicity in rats in vivo. Springerplus. 2015; 4: 619.

5. Bernhoft RA. Cadmium Toxicity and Treatment. The Scientific World Journal. 2013: 1-7.

6. Arroyo VS, Flores KM, Ortiz LB, Gomez-Quiroz LE, Gutierrez-Ruiz MC. Liver and Cadmium Toxicity. J Drug Metab Toxicol. 2016; 5:1-7.

7. Jacobo-Estrada T, Santoyo-Sanchez M, Thevenod F, Barbier O. Cadmium Handling, Toxicity and Molecular Targets Involved during Pregnancy: Lessons from Experimental Models. Int. J. Mol. Sci. 2017; 18, 1590: 1-19.

8. Feugang JM, Konarski P, Zou D, Stintzing FC, Zou C. Nutritional and medicinal use of Cactus pear (Opuntia spp.) cladodes and fruits. Front Biosci. 2006; 1(11): 2574-2589.

9. Singh N, Pandey BR. Phyto-pharmatherapeutics of Cyperus rotundus L., Indian Journal of Natural Products and Recourses. 2012; 3(4):467-476.

10. Kumar M, Rani M, Meher B. Review on Pharmacology and Phytochemistry of Cyperus rotundus L. Current Research in Pharmaceutical Sciences. 2017; 07 (01): 11-15.

11. Sirivastav S. Cyperus rotundus (Nagarmotha)-An Important Medicinal plant: A Review. I J P R. 2015; 1(1): 11-22.

12. Harborne JB. Phytochemical Methods, A guide to modern techniques of plant analysis. 2nd. ed. Chapman and Hail Ltd. , London 1984.

13. Bhandary SK, Kumari SN, Bhat SKP, Bekal MP. Preliminary phytochemical screening of various extracts of Punica Granatum peel, whole fruit and seeds. Nitte university journal of health science. NUJHS. 2012; 2(4): 34-38.

14. Harborne JB. Phytochemical methods, Science paper blacks.Chapman and Hall. London. 1973.

15. NigamV, Mishra MK, Biswal PK. Qualitative screenings of phytochemicals and antihyperglycaemic activity on leaves of Urtica Dioica using streptozotocin induced diabetic mice model. World Journal of Pharmacy and Pharmaceutical Sciences. 2014; 3(3): 934-948.

16. Al Albani M R. Effect of crude extracts and alkaline vasculine for the plant of Adhatoda vasica in some pathogenic bacteria. Master Thesis, College of Science - University of Baghdad. 2003; p.34.

17. Jaffer HJ, Mahmood MJ, Jawad AM, Naji A, ALNaib A. Phytochemical and biolgical screening of some Iraqi plant. Fitoterpia,LIX. 1983: pp: 299.

18. Balducci RE, Silvirio K, Gorge M, Ganazaga, H. Effect of isotretior on tooth germ of palate development in mouse embryos. Braz. Dent. J. 2001; 12(2): 115-119.

19. Gidado A, Ameh DA, Atawodi SE. Effect of Nauclea latifolia leaves aqueous extract on blood glucose levels of normal and alloxan-induced diabetic rats. Afr. J. Biotech. 2005; (4): 91-93.

20. Evcimen M, Demirel HH, Demirel R, Gulay MS. For Rats Which are Implemented Cadmium Chloride Exposure, Polydatin and Grape Seed Extracts 
Protective Effects on Testis and Brain Tissues. Veterinary science. 2015; 4(10). 307-310.

21. Guidet B, shah SV. Am J. Physiol. 1989; 257(26):440. cited by Muslih RK, Al-Nimer MS, AlZamely OY. The level of Malondialdehyde after activation with $\mathrm{H}_{2} \mathrm{O}_{2}$ and $\mathrm{CuSO}_{4}$ and inhibition by deferoxamine and Molsidomine in the serum of patient with acute Myocardial infarction. National journal of chemistry. 2002; (5): 139-148.

22. Tietz NW. Textbook of clinical chemistry. $3^{\text {rd }}$ ed. C.A.Burtis, E.R.Ashwood, W.B.Saunders. 1999; Pp: 819-861,1245-1250.

23. Sedlak J, Lindsay RH. Analytical biochemistry.1968; Pp: 192. Cited by Al-Zamyle(2001).

24. Vanuffelen BE, VanDerzec J, Dekoster BM. Detection the level of peroxynitrite and related with antioxidants status in the Serum of patients with acute myocardial infraction national. Biochem. J. 1998; 330.719. Cited by Al-Zamely et al (2001).

25. Tietz NW. Fundamentals of clinical chemistry. W.B.Saunders Co, Philadelphia, USA. 1987; Pp: 940.

26. Al-Snafi E. A review on Cyperus rotundus A potential medicinal plant. IOSR Journal Of Pharmacy. 2016; 6(7) Version. 2: 32-48.

27. Asagba SO, Eriyamremu GE. Oral cadmium exposure alters haematological and liver function parameters of rats fed a Nigerian like diet. Journal of Nutritional and Environmental Medicine.2007; 16(34):267-274.

28. Naik P. Biochemistry 3rd ed. Jaypee Publishers Ltd, Panama. 2010; p138-141, 565.

29. Mauro P, Renze B. In: Fundamentals of Clinical Chemistry. 6th ed. 2008; p325.

30. Kuester RK, Waalkes MP, Goering PL, Fishers BL, Micuskey RS, Sipes IG. Differential hepatotoxicity induced by cadmium in Fisher 344 and Sprague Dawley rats. Toxicol Sci. 2002; 65:151-9.

31. Manna C, Migliardi V, Sannino F, DeMartino A, Capasso R. Protective effects of synthetic hydroxytyrosol acetyl derivatives against oxidative stress in human cells. J. Agric. Food Chem. 2005; 53: 9602-9607.

32. Misra R, Smith G, Waalkers M. Evaluation of the genotoxic potential of cadmium in four different rodent cell lines. Toxicol. 1998; 126: 103-114.

33. Adefegha SA, Omojokun OS, Oboh G. Modulatory effect of protocatechuic acid on cadmium induced nephrotoxicity and hepatoxicity in rats in vivo. SpringerPlus. 2015; 4:619.

34. Guyton AC, Hall JE. Text book of medical physiology. $11^{\text {th }} \mathrm{ed}$, Elsevier science, Philadelphia. 2006; Pp: 1014-1073.

35. Bartosikova L, Necas J, Suchy V, Kubinova R, Vesel $\mathrm{D}$, Benes, L, et al. Monitoring of antioxidatve effect of morin in alloxan-induced diabetes mellitus in the laboratory rat. Acta. Vet. Brno. 2003; 72: 191-200.

36. Ramamurthy CH, Subastri A, Suyavaran A, Subbaiah KC, Valluru L, Thirunavukkarasu C. Solanum torvum Swartz. Fruit attenuates cadmium-induced liver and kidney damage through modulation of oxidative stress and glycosylation. Environ Sci Pollut Res Int. 2016; 23: 7919-7929.
37. Wang Y, Wu Y, Luo K, Liu Y, Zhou M, Yan S, et al. The protective effects of selenium on cadmiuminduced oxidative stress and apoptosis via mitochondria pathway in mice kidney. Food Chem Toxicol. 2013; 58: 61-67.

38. Atalay M, El-Aaksonen D. Diabetes oxidative stress and physical exercise. J. of Spo Sci and Med. 2002; 1: $1-14$.

39. Roopha PD, Michael SJ, Padmalatha C, Ranjit Singh RJA. Cadmium toxicity exposure Induced oxidative stress in postnatal development of wistar rats. Journal of Toxicology and Environmental Health Sciences. 2011; 3(7): 176-179.

40.Zheng JL, Yuan SS, Wu CW, Lv ZM. Acute exposure to waterborne cadmium induced oxidative stress and immunotoxicity in the brain, ovary and liver of zebrafish (Danio rerio). Aquat Toxicol. 2016; 180: 36-44.

41. Dkhil MA, Al-Quraishy S, Diab MM, Othman MS, Aref AM, Abdel Moneim AE. The potential protective role of Physalis peruviana $\mathrm{L}$. fruit in cadmium-induced hepatotoxicity and nephrotoxicity. Food Chem Toxicol. 2014; 74: 98-106.

42. Ferdinandy,P. Peroxynitrite: Just an oxidative/nitrosative stress or a physiological regulator as well. Br J Pharmacol. 2006; 148: 1-3.

43. Dukic NM. Antioxidants in health and diseases. Atherosclerosis. 2003; 15(2): 423-477.

44. Haouem S, El-Hani A. Effect of Cadmium on Lipid Peroxidation and on Some Antioxidants in the Liver, Kidneys and Testes of Rats Given Diet Containing Cadmium-polluted Radish Bulbs. J Toxicol Pathol. 2013; 26: 359-364.

45. Fisher CJ. Organoselenium compounds as glutathione peroxi-dase mimics. B-180 Medical Laboratories Free Radical and Radiation Biology Program, University of Iowa. 2003; 77: 222.

46. Necib Y, Bahi A, Zerizer S, Abdennour C, Boulakoud MS. Hepatoprotective role of sodium selenite against oxidative damage induced by mercuric chloride in rat albinos wistar. Journal of stress physiology and biochemistry. 2013; 9(4): 230240.

47. Muchtaromah B, Kiptiyah, Adi TK. Transaminase enzyme and liver histological profile of mice administered extract of pegagan (Centella asiatica (L) urban). Med. Pet. 2011; 34(2): 88-92.

48. Pari L, Karthikesan K. Protective role of caffeic acid against alcohol Induced biochemical changes in rats. Fundam Clin Pharmacol. 2007; 21(4): 355-361.

49. Naimi, SMA. Effect of boiled water extract of Cyperus rotundus plant tubers in some physiological and chemical properties of life in broiler. Iraqi J. Vet. Sci. 2009; 23: 298-293.

50. Silpa S, Takreem A, Sekhar V. Antidiabetic and Wounhealing Acyivity of stem ethanolic extract of Cyperus rotundus in Alloxan induced Diabetic rats. IAJPR. 2014; 4(09): 3808-3816.

51. Gray AM, Flatt PR. Insulin releasing and insulin like activity of the traditional antidiabetic plant. Coriandrum sativum (Coriander). Br. J. Nutr. 1999; 81(3): pp.203-209. 
52. Bando I, Rens M I, Andres D, Cascales M. Endogenous antioxidant defence system in rat liver following mercuric chloride oral intoxication. Journal of Biochemical Molecular and Toxicology. JBMT. 2005; 19(3): 154-161.

53. Kilani SA, Abdelwahed I, Chraief R, Ben Ammar N, Hayder M, Hammami K,et al. Chemical composition, antibacterial and antimutagenic activities of essential oil from (Tunisian) Cyperus rotundus. Journal Essential Oil Research. 2005; 17: 695-700.

54. Oladipupo AL, Oyedeji AO. Chemical composition of the essential oils of Cyperus rotundus L. from South Africa. Molecules. 2009; 14:2909-2917.
55. Ozkol H, Musa D, Tuluce Y, Koyuncu I. Ameliorative influence of Urtica dioica $\mathrm{L}$ against cisplatin-induced toxicity in mice bearing Ehrlich ascites carcinoma. Drug and Chemical Toxicology. 2012; 35(3): 251-257.

56. Nagulendran KR, Velavan S, Mahesh R, Hazeena Begum V. In Vitro Antioxidant Activity and Total Polyphenolic Content of Cyperus rotundus Rhizomes. E-Journal of Chemistry. 2007; 4(3): 440449.

\section{تاثير المستخلص المائي لارنات نبات السعد Cyperus rotundus كمضاد للاكسدة في وظائف الكبا والكلى لأكور الجرذان البيض البئ المعرضة للتسمم بكلوريد الكادميوم

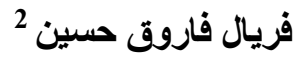

\author{
عدنان محمد أحميد الاليمي 1
}

1 مديرية تربية صلاح الدين، وزارة التربية، صلاح الدين، العراق.

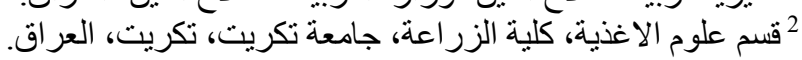

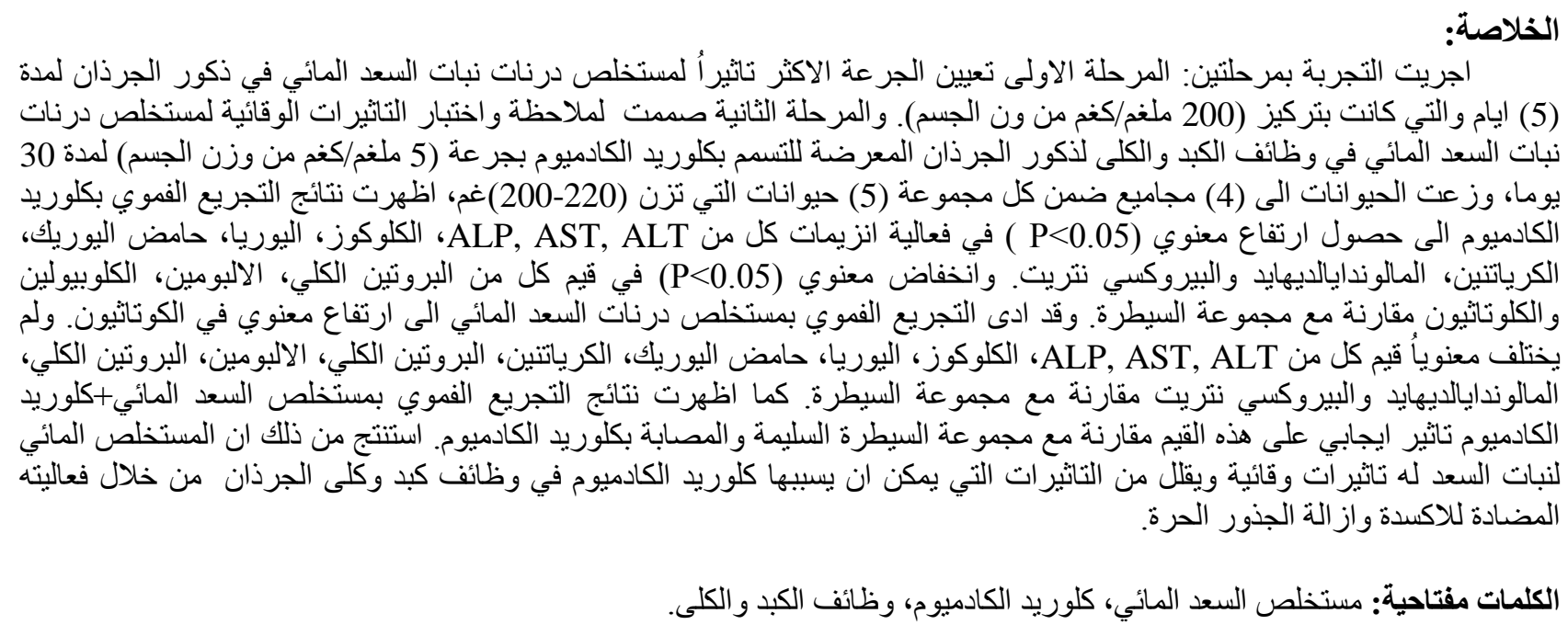

